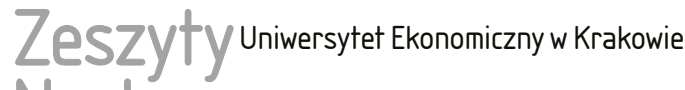 Naukowe
}

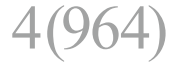

ISSN 1898-6447

Zesz. Nauk. UEK, 2017: 4(964): 67-80 DOI: 10.15678/ZNUEK.2017.0964.0404

\author{
Anna Rakowska \\ Iwona Mendryk
}

\section{Satysfakcja i zaangażowanie kadry kierowniczej w innowacyjnych przedsiębiorstwach - wyniki badań}

\section{Streszczenie}

Zaangażowana kadra kierownicza ma duży wpływ na osiągane przez organizację wyniki. Istotne są w tym przypadku trzy rodzaje zaangażowania: zaangażowanie w pracę, zaangażowanie w wykonywany zawód oraz przywiązanie do organizacji, dlatego ważne jest poznanie czynników kształtujących ich poziom. Badacze często wskazują na związki między zaangażowaniem a satysfakcją. Celem artykułu jest ocena poziomu zaangażowania i satysfakcji z pracy kierowników, porównanie wyników osiąganych w tym zakresie z wynikami pracowników zatrudnionych na stanowiskach niekierowniczych oraz określenie siły związków między trzema rodzajami zaangażowania a satysfakcją kierowników z warunków ekonomicznych, wykonywanych zadań, relacji interpersonalnych oraz otoczenia fizycznego. Zwrócono uwagę na czynniki organizacyjne, tj. postrzegane wsparcie i poczucie sprawiedliwości. Stwierdzono występowanie związków między trzema rodzajami satysfakcji a poszczególnymi rodzajami zaangażowania, przy czym siła tych związków jest zróżnicowana. Uzyskane wyniki mogą być pomocne w efektywniejszym wykorzystaniu potencjału kadry kierowniczej przez kształtowanie jej zaangażowania.

Anna Rakowska, Uniwersytet Marii Curie-Skłodowskiej w Lublinie, Wydział Ekonomiczny, Zakład Zarządzania Zasobami Ludzkimi, pl. M. Curie-Skłodowskiej 5, 20-031 Lublin, e-mail: a.rakowska@poczta.umcs.lublin.pl

Iwona Mendryk, Uniwersytet Marii Curie-Skłodowskiej w Lublinie, Wydział Ekonomiczny, Zakład Zarządzania Zasobami Ludzkimi, pl. M. Curie-Skłodowskiej 5, 20-031 Lublin, e-mail: iwona.mendryk@poczta.umcs.lublin.pl 
Słowa kluczowe: satysfakcja, zaangażowanie w pracę, przywiązanie, zaangażowanie w zawód.

Klasyfikacja JEL: M12, M14, M54.

\section{Wprowadzenie}

Zaangażowana kadra kierownicza stanowi cenny zasób każdej organizacji. Kierownicy pełni energii i pozytywnie nastawieni do swojej pracy lepiej radzą sobie z wyzwaniami, mają więcej pomysłów, tworzą odpowiedni klimat organizacyjny i mają pozytywny wpływ na swoich podwładnych. Jak pokazują badania, takich kierowników i pracodawców nie brak także na polskim rynku [Budowanie zaangażowania... 2013]. Według organizatora corocznego konkursu Aon Najlepsi Pracodawcy, przedsiębiorstwa, które angażują pracowników: „mają silne umiejętności przyciągania, utrzymywania i rozwijania talentów. Zaangażowani pracownicy osiągają lepsze rezultaty, co wpływa na lepsze wyniki finansowe, a pracownicy w większym stopniu przyczyniają się do sukcesu klientów firmy" [Znamy już Najlepszych Pracodawców... 2016].

W literaturze można znaleźć wiele badań na temat uwarunkowań związanych z zaangażowaniem [Lewicka 2014]. Jednym z najczęściej wymienianych czynników jest satysfakcja (w bazie Google Scholar znaleźć można 416 tys. publikacji na jej temat datowanych od 2013 r.). Trudno jednak jednoznacznie określić, czy to satysfakcja wpływa na zaangażowanie, czy odwrotnie. Mimo to nie ulega wątpliwości, że oba wymienione czynniki są ważnymi aspektami zarządzania w każdej organizacji, a w szczególności w przedsiębiorstwach innowacyjnych [Daveloo $i$ in. 2015].

Wśród uwarunkowań związanych z satysfakcją i zaangażowaniem często wymieniane są praktyki HR [Albrecht i in. 2015, Lewicka i Rakowska 2016]. Szczególne znaczenie ma wpływ postrzegania tych praktyk na zachowania pracowników, w tym także na zaangażowanie w pracę i przywiązanie do organizacji [Lewicka i Krot 2015, Ostroff i Bowen 2016].

Celem artykułu jest ocena poziomu satysfakcji z pracy i zaangażowania kadry kierowniczej innowacyjnych polskich przedsiębiorstw. Dla jego realizacji wykorzystano wyniki badań przeprowadzonych w 2015 i 2016 r. za pomocą kwestionariusza ankiety na próbie 2076 pracowników z 50 innowacyjnych przedsiębiorstw, wśród których było 387 menedżerów ${ }^{1}$. Do analizy materiału empirycznego zastosowano statystyki opisowe oraz testy porównywania średnich (jednoczynnikową

${ }^{1}$ Badania zrealizowano w ramach projektu pn. „Potencjał kompetencyjny wybranych grup pracowników w aspekcie zarządzania różnorodnością w innowacyjnych przedsiębiorstwach" (umowa nr UMO-2013/09/B/HS4/01307). 
analizę wariancji ANOVA). W ten sposób zyskano możliwość zaprezentowania wyników samooceny kierowników w zakresie badanych zmiennych, jak i stwierdzenia różnic między wynikami osiągniętymi przez kierowników i pozostałych badanych (zatrudnionych na stanowiskach wykonawczych i specjalistycznych).

\section{Satysfakcja z pracy i czynniki kształtujące poziom satysfakcji}

Satysfakcja z pracy ma duże znaczenie dla zrozumienia i wyjaśnienia zachowań ludzi w organizacji. Wpływa ona m.in. na absencje, wypalenie zawodowe, wellbeing [Mathieu i in. 2014], zaangażowanie w pracę [Biswas i Bhatnagar 2013, Rich, Lepine i Crawford 2010], przywiązanie do organizacji [Mendryk 2016], sukces organizacji [Kopertyńska i Kmiotek 2016].

Najogólniej satysfakcja z pracy może być interpretowana jako pozytywny stosunek zatrudnionych do powierzonych im obowiązków, otoczenia pracy i współpracowników. V.H. Vroom [1964] definiuje satysfakcję jako pozytywy stosunek jednostki do funkcji, jaką ona pełni. Może też być ona określona jako „przyjemny pozytywny stan emocjonalny, wynikający z postrzegania własnej pracy jako spełniającej lub pozwalającej na realizację w pracy ważnych wartości, które są zgodne z potrzebami fizycznymi i psychicznymi" [McPhee i Townsend 1992]. Satysfakcja z pracy może być rozwijana przez reakcje poznawcze i afektywne pracowników wobec swoich zadań. W tym kontekście satysfakcja z pracy jest kombinacją zarówno aspektu afektywnego (tego, co jednostka czuje) i kognitywnego (tego, co jednostka myśli) na temat poszczególnych aspektów swojej pracy. Dodać należy także, że w niektórych pracach obok terminu satysfakcja pojawia się zadowolenie z pracy [Juchnowicz 2014]. Dla celów tej publikacji przyjęto definicję satysfakcji według E.A. Locke’a (za: [Saarii i Judge 2004, s. 396]), zgodnie z którą satysfakcja z pracy to przyjemny pozytywny stan emocjonalny, który jest efektem oceny wykonywanej pracy oraz związanych z pracą doświadczeń.

W badaniach nad satysfakcją można wyróżnić dwa podejścia - pierwsze koncentruje się na badaniu ogólnej satysfakcji, a drugie na poszczególnych jej aspektach (m.in. aspektach ekonomicznych, relacjach międzyludzkich, treści pracy i zadaniach, fizycznych warunkach) [Coomber i Barriball 2007]. Popularnością cieszy się podział czynników związanych z satysfakcją nawiązujący do dwuczynnikowej teorii F. Herzberga [Herzberg 1966, Kaasa 2011]. Rolę czynników sytuacyjnych w kształtowaniu satysfakcji potwierdzają m.in. X. Huang i E. Van de Vliert [2003] oraz C. Mottaz [1985]. T.A. Judge i in. [2010] dowiedli, że wysokość płacy w niewielkim stopniu wpływa na poziom satysfakcji pracownika. 


\section{Zaangażowanie i jego rodzaje}

Problematyka zaangażowania pracowników stała się w ostatnich latach popularna zarówno wśród badaczy, jak i wśród praktyków. Duże znaczenie miały w szczególności prace z lat 90., takich badaczy jak W.A. Kahn [1990], C. Maslach i M.P. Leiter [1997], czy N.J. Allen i J.P. Mayer [1990]. Opracowania na ten temat można analizować w kontekście [Rakowska i Mącik 2015]:

- historii rozwoju koncepcji zaangażowania i jej kamieni milowych,

- koncepcji i definicji zaangażowania (rozróżnienie terminów engagement, commitment i involvement oraz rozróżnienie rodzajów zaangażowania, w tym: job engagement i organizational engagement),

- czynników mających wpływ na poziom zaangażowania,

- pomiaru zaangażowania,

- efektów zaangażowania.

Dorobek w tym zakresie jest imponujący, nastręcza jednak problemów metodologicznych, przede wszystkim jeśli chodzi o definiowanie zaangażowania i jego poszczególnych rodzajów, tj. zaangażowania w pracę (job engagement), zaangażowania w zawód (job involement) i przywiązania do organizacji (organizational commitment). Przyjęto, że zaangażowanie w pracę, zaangażowanie w zawód i przywiązanie do organizacji są trzema zbliżonymi, ale jednak różniącymi się od siebie koncepcjami.

Termin „zaangażowanie w pracę” często pojawia się w obszarze psychologii zdrowia i pracy w kontekście wellbeing. Zaangażowanie w pracę jest postrzegane jako przeciwieństwo wypalenia zawodowego [Schaufeli i in. 2002, s. 74]. Na zaangażowanie w pracę składają się trzy komponenty: wigor (vigor) rozumiany i mierzony jako poziom energii i psychicznej odporności w pracy, oddanie pracy (dedication) wynikające z dumy ze swojej pracy i gotowości identyfikowania się $\mathrm{z}$ nią oraz pochłonięcie pracą (absorption) przejawiające się skupieniem na pracy i trudnościami z oderwaniem się od niej. Jednym z bardziej uznanych narzędzi pomiaru zaangażowania w pracę jest skala UWES (Utrecht work engagement scale), nazywana również skalą Utrechta [Schaufeli i in. 2002]. W.B. Schaufeli i M. Salanova definiują zaangażowanie jako pozytywne spełnienie związane ze stanem umysłu charakteryzowanym przez wigor, oddanie pracy i pochłonięcie pracą. Trzy wymienione obszary zaangażowania w pracę występują w skali UWES.

Nieco innym rodzajem zaangażowania jest zaangażowanie w zawód. Jest ono ważne dla profesjonalistów, w tym dla kadry kierowniczej. W literaturze można spotkać dwa podejścia do zaangażowania w zawód. Pierwsze koncentruje się na tym, jak praca wpływa na samoocenę danej osoby. Jego twórcami są T. Lodahal i M. Kejner [1965]. Drugie koncentruje się na tym, jak praca wpływa na tożsamość człowieka. 
Najbardziej rozwiniętą koncepcją zaangażowania w zawód jest koncepcja S.P. Browna [1996, s. 232], który przyjmuje motywacyjne podejście do zaangażowania w zawód. Podkreśla poznawcze i psychologiczne aspekty identyfikacji z pracą, która według niego może zaspokajać najgłębsze potrzeby i oczekiwania człowieka. Zdaniem S.P. Browna osoba zaangażowana w zawód to taka, która: 1) postrzega swoją pracę jako motywującą i pełną wyzwań; 2) jest zaangażowana w samą pracę (work), w zawód (job) oraz w organizację; 3) angażuje się w bliskie zawodowe relacje np. z kolegami i zwierzchnikami, a także otrzymuje od nich informacje zwrotne. Zaangażowanie w zawód pozostaje w dużej mierze pod wpływem czynników osobowościowych, charakteru pracy, zachowań przełożonych oraz percepcji roli.

Trzecim rodzajem zaangażowania jest zaangażowanie w organizację, często określane mianem przywiązania do organizacji [Bańka, Bazińska i Wołowska 2002]. Ten rodzaj zaangażowania odnosi się do emocjonalnego przywiązania, tj. do związku pracownika z organizacją opartego na wspólnych wartościach i interesach. N.J. Allen i J.P. Meyer [1990] wyróżniają trzy rodzaje przywiązania: afektywne, kalkulacyjne i normatywne. Przywiązanie afektywne oznacza emocjonalne przywiązanie pracownika do organizacji. Przywiązanie kalkulacyjne ma charakter instrumentalny. Wynika ono z przekonania, że koszty opuszczenia organizacji byłyby zbyt wysokie i/lub alternatywne możliwości zatrudnienia nie istnieją. Przywiązanie normatywne jest związane z poczuciem moralnego obowiązku kontynuowania zatrudnienia, jego wyrazem jest lojalność wobec organizacji. W badaniach dużo uwagi poświęcono związkowi przywiązania do organizacji z chęcią jej opuszczenia, przyjmując, że pracownik mocno przywiązany do organizacji rzadziej myśli o odejściu z niej. P.C. Morrow [1983] uważa, że przywiązanie do organizacji jest w większym stopniu zależne od czynników zewnętrznych wobec pracy niż od czynników osobistych, włączając w to wewnętrzną motywację. J.E. Mathieu i D.M. Zajac [1990] dokonali metaanalizy w zakresie czynników kształtujących przywiązanie do organizacji, wśród nich znalazły się m.in. satysfakcja z poszczególnych aspektów pracy, zaangażowanie w zawód, chęć opuszczenia organizacji. W kształtowaniu zaangażowania i przywiązania ważną rolę odgrywają także postrzegane wsparcie ze strony organizacji, poczucie sprawiedliwości i postrzeganie praktyk ZZL [Cheng 2014, Kurtessis i in. 2015, Mendryk i Rakowska 2016, Colakoglu, Culha i Atay 2010].

\section{Zaangażowanie i satysfakcja kadry kierowniczej - wyniki badań}

Poniżej zaprezentowano wyniki badań, które są częścią badań zrealizowanych w ramach grantu badawczego dotyczącego oceny i wykorzystania potencjału 
kompetencyjnego pracowników innowacyjnych przedsiębiorstw. W projekcie wzięło udział 2076 pracowników z 50 innowacyjnych przedsiębiorstw.

Dobór próby był celowy. Do badania zakwalifikowano przedsiębiorstwa innowacyjne. Przyjęto definicję innowacyjności za podręcznikiem Oslo Manual 2005, w którym definicja innowacji obejmuje pełne spektrum nowości - od nowości na skalę światową (tzw. innowacje absolutne) po nowości w skali rynku, na którym działa przedsiębiorstwo. Pod uwagę brane są cztery rodzaje innowacji: produktowe, procesowe, organizacyjne oraz marketingowe. Przedsiębiorstwa, które wzięły udział w badaniach, znajdowały się jednocześnie na listach innowacyjnych przedsiębiorstw sporządzanych w latach 2012-2014 (m.in. www.pi.gov. pl/PARP, http://inwestor.wup-krakow.pl/artykuly/1959/Raport-o-innowacyjnoscigospodarki-Polski-w-2012-roku, http://www.wprost.pl/ar/421276/, www.optel.eu).

W częśsi badań dotyczącej wykorzystania potencjału kompetencyjnego kierowników poszukiwano odpowiedzi na pytania:

1) jaki jest poziom zaangażowania w pracę, przywiązania do organizacji oraz zaangażowania w zawód kadry kierowniczej badanych przedsiębiorstw?

2) jaki jest poziom satysfakcji z warunków ekonomicznych, z zadań i charakteru pracy, $\mathrm{z}$ relacji interpersonalnych, $\mathrm{z}$ otoczenia fizycznego $\mathrm{w}$ pracy?

3) czy występują różnice w poziomie zaangażowania i satysfakcji z pracy między kierownikami a pracownikami zatrudnionymi na stanowiskach wykonawczych i specjalistycznych.

Badania przeprowadzano z wykorzystaniem kwestionariusza ankiety. Do opracowania ankiety w części dotyczącej zaangażowania wykorzystano koncepcję N.J. Allena i J.P. Meyera [1990], koncepcję S.P. Browna [1996] oraz skalę Utrechta. W przeprowadzonych badaniach pilotażowych $(n=160)$ obliczone współczynniki $\alpha$-Cronbacha były wyższe od 0,76 .

W próbie badawczej w grupie obejmującej kadrę kierowniczą znalazło się 387 kierowników, z których większość miała wyższe wykształcenie (90\%). W grupie tej $37 \%$ stanowiły kobiety, a $63 \%$ mężczyźni. Średni wiek respondentów to 44 lata, średni staż ogółem 25,5 roku, a staż na stanowisku 8,5 roku. Wśród badanych kierowników 18\% stanowiły osoby w wieku 25-34 lat, 39\% w wieku 35-44 lat, 27\% w wieku od 45-54 lat, a 6\% miało 55 lat i więcej.

Pozostałą część próby (1698 osób) stanowili zatrudnieni na stanowiskach specjalistycznych i wykonawczych. Duże różnice w liczebności grup respondentów wyróżnionych ze względu na zajmowane stanowisko spowodowały konieczność losowania z grupy badanych pracowników zatrudnionych na stanowiskach wykonawczych i specjalistycznych. W ten sposób uzyskano trzy grupy liczące po 387 osób i dla nich wykonano wszystkie obliczenia.

Pierwszy obszar analizy stanowiła ocena poziomu każdego z trzech rodzajów zaangażowania, tj. zaangażowania w pracę, przywiązania do organizacji oraz zaan- 
gażowania w zawód. Respondenci zostali poproszeni o ocenę poziomu swojego zaangażowania w skali 1-5 (1 - zdecydowanie się nie zgadzam; 2 - raczej się nie zgadzam; 3 - ani się zgadzam, ani się nie zgadzam, trudno ocenić; 4 - raczej się zgadzam; 5 - zdecydowanie się zgadzam). Odpowiedzi kierowników odniesiono do odpowiedzi pozostałych grup pracowników i przedstawiono w tabeli 1.

Tabela 1. Zaangażowanie w pracę, przywiązanie do organizacji, zaangażowanie w zawód według poszczególnych stanowisk (średnie wartości)

\begin{tabular}{|l|c|c|c|c|c|c|c|}
\hline \multirow{2}{*}{ Stanowisko } & \multicolumn{3}{|c|}{ Zaangażowanie w pracę } & \multicolumn{2}{c|}{ Przywiązanie do organizacji } & \multirow{2}{*}{ wigor } \\
\cline { 2 - 7 } & $\begin{array}{c}\text { oddanie } \\
\text { pracy }\end{array}$ & $\begin{array}{c}\text { pochło- } \\
\text { nięcie } \\
\text { pracą }\end{array}$ & $\begin{array}{c}\text { emocjo- } \\
\text { nalne }\end{array}$ & trwania & $\begin{array}{c}\text { norma- } \\
\text { tywne }\end{array}$ & $\begin{array}{c}\text { Zaangażowanie } \\
\text { w zawód }\end{array}$ \\
\hline Wykonawcze & 3,57 & 3,73 & 3,58 & 3,19 & 3,00 & 3,98 & 3,42 \\
\hline Specjalistyczne & 3,74 & 3,87 & 3,71 & 3,42 & 3,30 & 4,12 & 3,50 \\
\hline Kierownicze & 3,93 & 4,09 & 3,82 & 3,79 & 3,58 & 4,33 & 3,68 \\
\hline
\end{tabular}

Źródło: opracowanie własne.

Z analizy danych przedstawionych w powyższej tabeli wynika, że kadra kierownicza deklaruje wyższe zaangażowanie w każdym z trzech rodzajów zaangażowania w porównaniu z pozostałymi grupami pracowników, tj. pracowników wykonawczych i specjalistów. Różnice średnich są istotne statystycznie (zastosowano jednoczynnikową analizę wariancji $\left.\mathrm{ANOVA}^{2}, p<0,05\right)$. Wyniki dotyczące kadry kierowniczej można uznać za dobre i satysfakcjonujące w obszarze oddania pracy (przekonanie, że praca ma znaczenie, a jej wykonywanie jest ważne i może napawać dumą) i przywiązania normatywnego (traktowanie swojej obecności w organizacji jako rodzaju powinności). Nieco słabsze wyniki dotyczą przywiązania trwania, związanego z potrzebą kontynuowania pracy dla organizacji wobec postrzeganych kosztów i strat wynikających z odejścia z organizacji oraz ograniczonych alternatyw na rynku pracy. Może to oznaczać, że gdyby kierownicy otrzymali lepszą ofertę pracy, rozważaliby odejście z organizacji. W tym obszarze niepokojące są wyniki w grupie pracowników wykonawczych, co oznacza, że spora grupa badanych pracuje w organizacji głównie dlatego, że nie ma możliwości znalezienia innej pracy.

${ }^{2}$ Zastosowanie jednoczynnikowej analizy wariancji poprzedziło sprawdzenie założeń teoretycznych dla tego typu testów. Zastosowano test K-S, by sprawdzić normalność rozkładu każdej zmiennej. Nie było podstaw do odrzucenia hipotezy o normalności rozkładu na poziomie istotności równym 0,05. Następnie zastosowano test Levene'a, aby sprawdzić hipotezę o jednorodności wariancji. Wynik tego testu również nie dał podstaw do odrzucenia tej hipotezy. Równoliczność porównywanych grup zagwarantowano, przeprowadzając losowanie z grup, które miały większe liczebności niż grupa kierowników. 
Zaangażowanie kierowników w zawód kształtuje się na poziomie dostatecznym, co może oznaczać, że wykonywany zawód w przeciętnym stopniu kształtuje tożsamość respondentów. $Z$ drugiej strony można uznać to za podejście rozsądne i zinterpretować ten wynik jako umiejętność zachowywania równowagi miedzy pracą a życiem prywatnym. Nie stwierdzono istotnych statystycznie związków między poszczególnymi trzema rodzajami zaangażowania a wiekiem, płcią menedżerów, ogólnym stażem pracy i stażem na stanowisku.

Drugim obszarem badań była analiza satysfakcji z uwzględnieniem jej rodzajów, tj. satysfakcji z warunków ekonomicznych, satysfakcji z zadań i charakteru pracy, satysfakcji z relacji interpersonalnych oraz satysfakcji z otoczenia fizycznego. Zestawienie wyników dla trzech grup pracowników przedstawiono w tabeli 2 . Kadra kierownicza na tle pozostałych grup pracowników osiąga najwyższy poziom satysfakcji. Wynik średniej satysfakcji jest bliski 4, co należy ocenić pozytywnie. Różnice między średnimi dla poszczególnych grup pracowników są istotne statystycznie (zastosowano jednoczynnikową analizę wariancji ANOVA, $p<0,05)$. Kierownicy są zadowoleni z wykonywanej pracy oraz z fizycznych warunków pracy i relacji interpersonalnych. Nieco powyżej przeciętnej należy ocenić satysfakcję kierowników z warunków ekonomicznych. Nie jest to jednak sytuacja niepokojąca. W każdej z trzech grup pracowniczych najniższy poziom satysfakcji dotyczy warunków ekonomicznych. Nie stwierdzono istotnych statystycznie związków między satysfakcją a wiekiem, płcią kierowników, stażem ogólnym i stażem na stanowisku.

Tabela 2. Satysfakcja pracowników według zajmowanych przez nich stanowisk (wartości średnie)

\begin{tabular}{|l|c|c|c|c|c|}
\hline \multirow{2}{*}{ Stanowisko } & \multirow{2}{*}{$\begin{array}{c}\text { Satysfakcja } \\
\text { (ogółem) }\end{array}$} & $\begin{array}{c}\text { warunki } \\
\text { fizyczne }\end{array}$ & $\begin{array}{c}\text { warunki } \\
\text { ekonomiczne }\end{array}$ & $\begin{array}{c}\text { relacje inter- } \\
\text { personalne }\end{array}$ & $\begin{array}{c}\text { czynności/ } \\
\text { zadania }\end{array}$ \\
\hline Wykonawcze & 3,57 & 3,74 & 3,20 & 3,80 & 3,55 \\
\hline Specjalistyczne & 3,77 & 4,00 & 3,47 & 3,89 & 3,72 \\
\hline Kierownicze & 3,93 & 4,19 & 3,75 & 3,19 & 3,93 \\
\hline
\end{tabular}

Źródło: opracowanie własne.

Trzecim badanym obszarem było wsparcie ze strony organizacji (zarówno przełożonego, jak i całej organizacji) oraz poczucie sprawiedliwości (proceduralnej i dystrybucyjnej). Poziom postrzeganego wsparcia i poczucia sprawiedliwości prezentuje tabela 3 . W tym przypadku również kadra kierownicza osiąga najwyższe wyniki na tle pozostałych pracowników (różnice średnich są istotne statystycznie, poziom istotności równy 0,05 ). Wyniki wskazują, że kadra nie 
odczuwa wystarczającego wsparcia ze strony swoich zwierzchników i całej organizacji. Stosowane procedury podziału zasobów (wynagrodzenia, podział premii i innych świadczeń) są postrzegane jako nie do końca obiektywne i sprawiedliwe.

Tabela 3. Wsparcie i poczucie sprawiedliwości postrzegane przez pracowników według zajmowanych przez nich stanowisk (wartości średnie)

\begin{tabular}{|l|c|c|}
\hline \multicolumn{1}{|c|}{ Stanowisko } & Postrzegane wsparcie & Postrzegana sprawiedliwość \\
\hline Wykonawcze & 3,22 & 3,00 \\
\hline Specjalistyczne & 3,31 & 3,18 \\
\hline Kierownicze & 3,48 & 3,41 \\
\hline
\end{tabular}

Źródło: opracowanie własne.

Aby zbadać siłę związków między zaangażowaniem (trzy rodzaje), satysfakcją (cztery obszary) a postrzeganym wsparciem i poczuciem sprawiedliwości, obliczono korelacje Pearsona (istotność na poziomie 0,01 ; tabela 4). Ze względu na siłę związku należy wyróżnić:

- korelację postrzeganego wsparcia z satysfakcją z relacji interpersonalnych $(r=0,59)$,

- korelację poczucia sprawiedliwości z satysfakcją z warunków ekonomicznych $(r=0,63)$,

- korelację między postrzeganym wsparciem a satysfakcją z wykonywanych zadań $(r=0,46)$,

- korelację między postrzeganym wsparciem a satysfakcją z warunków ekonomicznych $(r=0,48)$,

- korelację między satysfakcją z wykonywanych czynności a poczuciem sprawiedliwości $(r=0,40)$.

Obliczono także korelację między sumarycznym zaangażowaniem w pracę (suma wigoru, oddania pracy i pochłonięcia pracą) a satysfakcja z pracy (suma czterech aspektów). Wyniosła ona $r=0,50$ (istotność na poziomie 0,01 ), co oznacza, że jest to korelacja dosyć silna. $Z$ analizy wyników korelacji dla poszczególnych rodzajów zaangażowania (wigor, oddanie pracy i pochłonięcie pracą) wynika, że najsilniejsze związki satysfakcji dotyczą oddania pracy $(r=0,54)$ i wigoru $(r=0,44)$. W tym obszarze zaangażowania, tj. zaangażowania w pracę, największe znaczenie mają: postrzegane wsparcie (wsparcie-wigor $r=0,47$, wsparcie-oddanie pracy $r=0,56$ ) i poczucie sprawiedliwości (poczucie sprawiedliwości-oddanie pracy $r=0,49)$. Oddanie pracy jest także wyraźnie związane z satysfakcją z relacji interpersonalnych $(r=0,45)$, wykonywanymi czynnościami i zadaniami $(r=0,49)$. Niski poziom korelacji z pochłonięciem pracą pozwala wnioskować o większym wpływie czynników osobowościowych niż organizacyjnych na ten obszar zaan- 
gażowania. Co ciekawe, satysfakcja z warunków ekonomicznych nie ma silnego związku z zaangażowaniem $\mathrm{w}$ pracę.

Tabela 4. Korelacje między satysfakcją, zaangażowaniem a postrzeganym wsparciem i poczuciem sprawiedliwości* $(N=387)$

\begin{tabular}{|l|c|c|c|c|c|c|c|}
\hline \multirow{2}{*}{ Wyszczególnienie } & \multicolumn{3}{|c|}{ Zaangażowanie w pracę } & \multicolumn{2}{|c|}{ Przywiązanie do organizacji } & \multirow{2}{*}{ Zaangażowanie } \\
\cline { 2 - 7 } & wigor & $\begin{array}{c}\text { oddanie } \\
\text { pracy }\end{array}$ & $\begin{array}{c}\text { pochło- } \\
\text { nięcie } \\
\text { pracą }\end{array}$ & $\begin{array}{c}\text { emocjo- } \\
\text { nalne }\end{array}$ & trwania & $\begin{array}{c}\text { norma- } \\
\text { tywne }\end{array}$ & $\begin{array}{c}\text { Zawód } \\
\text { w zawn }\end{array}$ \\
\hline $\begin{array}{l}\text { Satysfakcja, w tym } \\
\text { związana z: }\end{array}$ & 0,44 & 0,54 & 0,26 & 0,37 & 0,53 & 0,35 & 0,46 \\
$\begin{array}{l}\text { warunkami } \\
\text { fizycznymi }\end{array}$ & 0,27 & 0,31 & 0,15 & 0,25 & 0,28 & 0,21 & 0,24 \\
\hline $\begin{array}{l}\text { warunkami } \\
\text { ekonomicznymi }\end{array}$ & 0,19 & 0,30 & 0,09 & 0,23 & 0,61 & 0,27 & 0,29 \\
\hline $\begin{array}{l}\text { relacjami } \\
\text { interpersonalnymi }\end{array}$ & 0,40 & 0,45 & 0,22 & 0,29 & 0,33 & 0,29 & 0,34 \\
\hline czynnościami & 0,39 & 0,49 & 0,28 & 0,28 & 0,24 & 0,21 & 0,44 \\
\hline Wsparcie & 0,47 & 0,56 & 0,23 & 0,39 & 0,54 & 0,33 & 0,50 \\
\hline Sprawiedliwość & 0,38 & 0,49 & 0,22 & 0,37 & 0,63 & 0,40 & 0,47 \\
\hline
\end{tabular}

* Korelacja $r$ Pearsona istotna na poziomie 0,01 (dwustronnie).

Źródło: opracowanie własne.

Jeśli chodzi o przywiązanie do organizacji, każdy z trzech rodzajów przywiązana (emocjonalne, trwania, normatywne) jest skorelowane z satysfakcją z pracy, przy czym najsilniejszy związek dotyczy przywiązania trwania $(r=0,53)$. To z kolei jest silnie związane z satysfakcją z warunków ekonomicznych $(r=0,61)$. Wsparcie ze strony organizacji i poczucie sprawiedliwości (odpowiednio: $r=0,54$, $r=0,63)$ są także wyraźnie związane z tym rodzajem przywiązania, co stwarza możliwości jego kształtowania. Natomiast satysfakcja z relacji interpersonalnych jest związana na poziomie przeciętnym $\mathrm{z}$ każdym $\mathrm{z}$ trzech rodzajów przywiązania.

Zaangażowanie w zawód jest najsilniej związane z satysfakcją z rodzaju wykonywanych zadań $(r=0,44)$. Nieznacznie silniejsze są związki zaangażowania w zawód z postrzeganym wsparciem ze strony organizacji oraz z poczuciem sprawiedliwości (odpowiednio: $r=0,50, r=0,47$ ). W tym przypadku także satysfakcja z warunków ekonomicznych nie ma dużego znaczenia dla kształtowania tego rodzaju zaangażowania.

Nie było możliwe zbudowanie modeli regresji dla poszczególnych rodzajów zaangażowania ze względu na występowanie współliniowości predyktorów (satysfakcja, wsparcie pracownika, poczucie sprawiedliwości). 


\section{Podsumowanie}

Ogólny poziom satysfakcji oraz poziom każdego z trzech rodzajów zaangażowania należy ocenić jako wyższy niż przeciętny, a w niektórych obszarach jako dobry. Nieco wyższy niż przeciętny jest poziom satysfakcji z warunków ekonomicznych oraz przywiązania trwania. Oznacza, to, że kierownicy nie są w pełni zadowoleni z otrzymywanego wynagrodzenia i nagród oraz z zasad ich podziału (wyniki w zakresie sprawiedliwości dystrybucyjnej i proceduralnej). Może to oznaczyć, że część z nich trwa w organizacji, ponieważ nie może znaleźć lepszej pracy lub koszty odejścia z organizacji są postrzegane jako duże.

Dobre są wyniki w zakresie satysfakcji z relacji interpersonalnych, fizycznych warunków pracy oraz wykonywanych zadań. Ogólny poziom zaangażowania w pracę można uznać za zbliżony do dobrego. Odnotowano wysoki poziom zaangażowania w pracę (oddanie pracy) i dobre wyniki w zakresie przywiązania normatywnego. Przeciętny wynik w obszarze zaangażowania w zawód może oznaczać, że kierownicy zachowują równowagę między pracą a życiem osobistym. Swoją tożsamość kształtują nie tylko przez wykonywany zawód, ale także przez podejmowanie innych aktywności.

Uzyskane wyniki świadczą o tym, że w procesie kształtowaniu zaangażowania w pracę większą rolę niż czynniki ekonomiczne odgrywają relacje interpersonalne, wykonywane czynności, wsparcie ze strony przełożonego i organizacji oraz poczucie sprawiedliwości. Warunki ekonomiczne i poczucie sprawiedliwości są jednak ważne w przypadku przywiązania trwania.

Podobnie jak w przypadku zaangażowania w pracę zaangażowanie w zawód można kształtować przez budowanie dobrych relacji interpersonalnych, odpowiednie przydzielanie zadań, udzielanie wsparcia, opracowywanie jasnych zasad podziału wynagrodzenia i nagród.

Wszystkie rodzaje zaangażowania są wyraźnie skorelowane z satysfakcją $\mathrm{z}$ relacji interpersonalnych, z postrzeganym wsparciem ze strony organizacji, z poczuciem sprawiedliwości, co oznacza, że możliwe jest zwiększanie zaangażowania przez kształtowanie odpowiedniej kultury organizacyjnej. Satysfakcja z warunków ekonomicznych (poza przywiązaniem trwania) nie ma tak dużego znaczenia w zwiększaniu zaangażowania kadry kierowniczej jak postrzegane wsparcie i sprawiedliwość (podobne wnioski można znaleźć w literaturze [Judge $i$ in. 2010]). Możliwe jest więc kształtowanie zaangażowania przez wprowadzanie i komunikowanie dobrych praktyk zarządzania, przy czym należy zwrócić szczególną uwagę na komunikowanie praktyk, tak aby były właściwie postrzegane przez kierowników [Ostroff i Bowen 2016]. Przyczyni się to nie tylko do zwiększania zaangażowania kierowników, ale także do wzrostu zaangażowania wszystkich pracowników. 


\section{Literatura}

Albrecht S.L., Bakker A.B., Gruman J.A., Macey W.H., Saks A.M. [2015], Employee Engagement, Human Resource Management Practices and Competitive Advantage: An Integrated Approach, ,,Journal of Organizational Effectiveness: People and Performance", vol. 2, nr 1, https://doi.org/10.1108/JOEPP-08-2014-0042.

Allen N.J., Meyer J.P. [1990], The Measurement and Antecedents of Affective, Continuance and Normative Commitment to the Organization, ,Journal of Occupational Psychology", vol. 63, nr 1, https://doi.org/10.1111/j.2044-8325.1990.tb00506.x.

Bańka A., Bazińska R., Wołowska A. [2002], Polska wersja Meyera i Allen Skali Przywiazania do Organizacji, „Czasopismo Psychologiczne”, nr 8(1).

Biswas S., Bhatnagar J. [2013], Mediator Analysis of Employee Engagement: Role of Perceived Organizational Support, P-O Fit, Organizational Commitment and Job Satisfaction, ,Vikalpa”, vol. 38, nr 1.

Brown S.P. [1996], A Meta-Analysis and Review of Organizational Research on Job Involvement, ,Psychological Bulletin”, vol. 120, nr 2, https://doi.org/10.1037/00332909.120.2.235.

Budowanie zaangażowania pracowników w GAZ-SYSTEM S.A. (9/12) [2013], GAZ-SYSTEM, http://www.gaz-system.pl/centrum-prasowe/aktualnosci/informacja/arty$\mathrm{kul} / 201751 /$ (data dostępu: 12.01.2017).

Cheng S.Y. [2014], The Mediating Role of Organizational Justice on The Relationship between Administrative Performance Appraisal Practices and Organizational Commitment, „The International Journal of Human Resource Management”, vol. 25, nr 8, https://doi.org/10.1080/09585192.2013.816864.

Colakoglu U., Culha O., Atay H. [2010], The Effects of Perceived Organizational Support on Employees' Affective Outcomes: Evidence from the Hotel Industry, „Tourism and Hospitality Management", vol. 16, nr 2.

Coomber B., Barriball K. [2007], Impact of Job Satisfaction Components on Intent to Leave and Turnover for Hospital Based Nurses: A Review of the Research Literature, „International Journal of Nursing Studies”, vol. 44, nr 2, https://doi.org/10.1016/j.ijnurstu.2006.02.004.

Devloo T., Anseel F., Beuckelaer A. De, Salanova M. [2015], Keep the Fire Burning: Reciprocal Gains of Basic Need Satisfaction, Intrinsic Motivation and Innovative Work Behavior, „European Journal of Work and Organizational Psychology”, vol. 24, nr 4, https://doi.org/10.1080/1359432X.2014.931326.

Herzberg F. [1966], Work and the Nature of Man, World Publishing, Cleveland.

Huang X., Vliert E. Van de [2003], Where Intrinsic Job Satisfaction Fails to Work: National Moderators of Intrinsic Motivation, ,Journal of Organizational Behavior”, vol. 24, nr 2, https://doi.org/10.1002/job.186.

Juchnowicz M. [2014], Satysfakcja z pracy determinantq jakości kapitału ludzkiego, PWE, Warszawa.

Judge T.A, Piccolo R.F. Podsakoff N.P., Shaw J.C, Rich B.L. [2010], The Relationship between Pay and Job Satisfaction: A Meta-analysis of the Literature, „Journal of Vocational Behavior", vol. 77, nr 2, https://doi.org/10.1016/j.jvb.2010.04.002.

Kaasa A. [2011], Work Values in European Countries: Empirical Evidence and Explanations, ,Review of International Comparative Management”, vol. 12, nr 5. 
Kahn W.A. [1990], Psychological Conditions of Personal Engagement and Disengagement at Work, „Academy of Management Journal”, vol. 33, nr 4, https://doi.org/ $10.2307 / 256287$.

Kopertyńska W., Kmiotek K. [2016], Zaangażowanie pracowników a sukces organizacji, „Zarządzanie i Finanse. Journal of Management and Finance”, vol. 14, nr 2/1.

Kurtessis J., Eisenberger R., Ford M.T., Buffardi L.C., Stewart K.A., Adis C.A. [2015], Perceived Organizational Support: A Meta-Analytic Evaluation of Organizational Support Theory, „Journal of Management”, vol. XX, nr X, https://doi.org/ $10.1177 / 0149206315575554$.

Lewicka D. [2014], The Influence of Organizational Trust upon Affective and Calculative Commitment, ,The Journal of American Academy of Business, Cambridge”, vol. 20, nr 1.

Lewicka D., Krot K. [2015], The Model of HRM-trust-commitment Relationships, ,Industrial Management and Data Systems”, vol. 115, nr 8, https://doi.org/10.1108/IMDS-122014-0388.

Lewicka D., Rakowska A. [2016], Wpływ praktyk ZZL na zaangażowanie pracowników w innowacyjnych przedsiębiorstwach, „Nauki o Zarządzaniu. Management Science”, nr 2(27), https://doi.org/10.15611/noz.2016.2.09.

Lodahl T., Kejner M. [1965], The Definition and Measurement of Job Involvement, ,Journal of Applied Psychology", vol. 49, nr 1, https://doi.org/10.1037/h0021692.

Maslach C., Leiter M.P. [1997], The Truth about Burnout: How Organizations Cause Personal Stress and What to Do about It, Jossey-Bass, San Francisco.

Mathieu C., Neumannc C.S,. Hareb R.D., Babiak P. [2014], A Dark Side of Leadership: Corporate Psychopathy and Its Influence on Employee Well-being and Job Satisfaction, ,Personality and Individual Differences”, vol. 59, https://doi.org/10.1016/j. paid.2013.11.010.

Mathieu J.E., Zajac D.M. [1990], A Review and Meta-Analysis of the Antecedents, Correlates, and Consequences of Organizational Commitment, „Psychological Bulletin”, vol. 108, nr 2, https://doi.org/10.1037/0033-2909.108.2.171.

McPhee S.D., Townsend L.J. [1992], A Study of Organizational Commitment and Job Satisfaction among Air Force Occupational Therapy Officers, ,Mil Med”, vol. 157, nr 3.

Mendryk I. [2016], Satysfakcja z pracy a preferowany wiek przechodzenia na emeryture. Wyniki badań, „Marketing i Rynek”, nr 3.

Mendryk I., Rakowska A. [2016], Wpływ postrzegania wsparcia organizacyjnego na postrzeganie zadowolenia z pracy i dobrostan pracowników w różnym wieku - wyniki badań, „Przedsiębiorczość i Zarządzanie”, t. XVII, z. 2, cz. 3.

Morrow P.C. [1983], Concept Redundancy in Organizational Research: The Case of Work Commitment, ,Academy of Management Review”, vol. 8, nr 3, https://doi.org/10.5465/ AMR.1983.4284606.

Mottaz C. (1985), The Relative Importance of Intrinsic and Extrinsic Rewards as Determinants of Work Satisfaction, ,The Sociological Quarterly”, vol. 26, nr 3, https://doi.org/ 10.1111/j.1533-8525.1985.tb00233.x.

Ostroff Ch., Bowen D. [2016], Reflections on the 2014 Decade Award: Is There Strength in the Construct of HR System Strength?, ,Academy of Management Review”, vol. 41, nr 2, https://doi.org/10.5465/amr.2015.0323. 
Rakowska A., Mącik R. [2015], Zaangażowanie pracownika a satysfakcja z pracy modelowanie zależności z wykorzystaniem PLS-SEM, „Przegląd Organizacji”, nr 5.

Rich B.L., Lepine J.A., Crawford E.R. [2010], Job Engagement: Antecedents and Effects on Job Performance, ,Academy of Management Journal”, vol. 53, nr 3, https://doi. org/10.5465/AMJ.2010.51468988.

Saari L., Judge T.A. [2004], Employee Attitudes and Job Satisfaction, „Human Resource Management", vol. 43, nr 4, https://doi.org/10.1002/hrm.20032.

Schaufeli W.B., Salanova M., Gonzalez-Roma V., Bakker A.B. [2002], The Measurement of Engagement and Burnout: A Two Sample Confirmatory Factor Analytic Approach, „Journal of Happiness Studies”, vol. 3, nr 1, https://doi.org/10.1023/A:1015630930326.

Vroom V.H. [1964], Work and Motivation, Wiley, New York.

Znamy już Najlepszych Pracodawców 2016! [2016], Aon, https://www.aon.com/poland/hr/ centrum_dla_mediow/Informacje_prasowe/2016/Informacja_prasowa_wyniki_PNP. jsp (data dostępu: 12.01.2017).

\section{Manager Satisfaction and Engagement in Innovative Enterprises - Research Results}

(Abstract)

Managerial engagement plays an important role in achieving organisational performance. Three types of behaviors and attitudes related to managers' performance should be considered: job engagement, work involvement, and organizational commitment. The literature indicates that numerous factors are relevant to high engagement, with satisfaction playing a particularly important role among them. The purpose of this article is to assess the level of commitment and satisfaction among managers, compare their results with those of non-management employees, and determine the strength of the relationships between the engagement (three types) and managerial job satisfaction with: economic conditions, their responsibilities, interpersonal relations and the physical environment. Organisational factors including perceived support and a sense of justice are also highlighted. The relationships between the three types of satisfaction and different types of engagement are identified; the strength of these relationships varied. The results obtained can be used to shape the commitment of managers and hence make more effective use of their potential.

Keywords: satisfaction, job engagement, commitment, work involvement. 